\title{
STATISTICAL DESIGN APPLICATION AND ANALYSIS OF SEPARATION EFFICIENCY IN DAVIS TUBE TESTER
}

\begin{abstract}
Mahmoud M. Ahmed
Mining and Metallurgical Engineering Department, Faculty of Engineering, Assiut University, Assiut 71516, Egypt
\end{abstract}

(Received May 3, 2010 Accepted June 9, 2010)

Wet low intensity magnetic separation studies for a synthetic binary mixture of magnetite and quartz were carried out. The variables studied were particle size, magnetic field intensity, and wash water rate. Experiments were carried out using $2^{3}$ full factorial designs. The main and interaction effects on the separation efficiency were evaluated using Yates' analysis. The optimum magnetic separation conditions were calculated by the method of steepest ascent. A concentrate with $98.9 \%$ magnetite at $87.2 \%$ component recovery and $86.3 \%$ separation efficiency was obtained at following optimum conditions: 200 um particle size, 3190 Gauss magnetic field intensity, and $402 \mathrm{~cm}^{3} / \mathrm{min}$ wash water rate.

KEYWORDS: Davis Tube, Separation Efficiency, Yates' Analysis, Interaction Effects, $t$-Test.

\begin{tabular}{|c|c|c|c|}
\hline \multicolumn{4}{|c|}{ NOMENCLATURE } \\
\hline$b_{j}$ & coefficient & $\underset{\text { (quartz) }}{\mathrm{R}_{\mathrm{c}}}$ & $\begin{array}{l}\text { component recovery of quartz } \\
\text { in concentrate }\end{array}$ \\
\hline $\mathrm{k}$ & $\begin{array}{l}\text { number of independent } \\
\text { variables (number of significant } \\
\text { coefficients in the regression } \\
\text { equation) }\end{array}$ & $\mathrm{t}$ & Student's t-test \\
\hline $\mathrm{n}$ & number of variables & $\mathrm{X}_{1}$ & particle size, $\mu \mathrm{m}$ \\
\hline $\mathrm{N}$ & number of trials & $\mathrm{X}_{2}$ & magnetic field intensity, Gauss \\
\hline$S . E_{\exp }$ & $\begin{array}{l}\text { experimental response } \\
\text { (separation efficiency), \% }\end{array}$ & $\mathrm{X}_{3}$ & wash water rate, $\mathrm{cm}^{3} / \mathrm{min}$ \\
\hline$\overline{S . E}_{\text {exp }}$ & $\begin{array}{l}\text { mean experimental value of } \\
\text { separation efficiency, } \%\end{array}$ & Y & response (separation efficiency) \\
\hline$S . E_{p r d}$ & $\begin{array}{l}\text { predicted separation efficiency, } \\
\%\end{array}$ & $\mathrm{Z}_{\mathrm{j} 0}$ & principal level \\
\hline $\begin{array}{l}\mathrm{R}^{2} \\
\mathrm{R}_{\mathrm{c}} \\
\text { (magnetite) }\end{array}$ & $\begin{array}{l}\text { coefficient of determination } \\
\text { component recovery of } \\
\text { magnetite in concentrate }\end{array}$ & $\frac{\Delta Z_{j}}{\sigma^{2}}$ & $\begin{array}{l}\text { increment } \\
\text { variance }\end{array}$ \\
\hline
\end{tabular}

\section{INTRODUCTION}

Magnetic separation is unquestionably the most effective way for concentration of magnetic ores [1]. Wet low intensity magnetic separators are widely used for treating 
fine ferromagnetic or some strongly paramagnetic minerals [2]. However, the necessity to grind the ores to increasingly finer sizes and generation of ultrafines thereby increases the difficulty to efficiently recover such fine particles. Therefore, it is necessary to find means to effectively apply magnetic concentration to ultra fine particles to determine the gradation of the most important variables which affect the separation process and find out the optimum conditions.

Many researchers have used the wet low intensity magnetic separator (Davis tube) as a tester in concentration of fine magnetic particles [2-8]. Arol and Aydogan [2] investigated the effect of a proper size enlargement process on the recovery of ultrafine particles. Rayner and Napier-Munn have determined the magnetics in the effluent streams [5]. The magnetic fraction of the concentrate and tailing samples in coal washing plants was recovered using the Davis tube [6]. It was used for the separation of directly reduced iron from calcium sulfide [8].

Ito et al. [4] investigated the magnetic separation of anode and cathode activating agents in the $<0.075 \mathrm{~mm}$ fraction of crushed cylindrical and prismatic types batteries. Davis tube was used for decreasing the chloride level and upgrading the zinc content of electric arc furnace steelmaking to give a zinc-rich product for smelting, an iron-rich product for dumping, and a treated solution for sewer discharge [3].

One of the most effective techniques to study process behavior is the factorial designed test with analysis of variance [9-14]. There are several advantages of statistical design of experiments over classical one variable at a time method, where one variable is varied at a time. In statistical design, experiments can be conducted in an organized manner and can be analyzed systematically to obtain much needed information. These information can be utilized for optimization purpose.

A review of magnetic separation literature indicates that there is a lack of statistically based studies on the effects and/or interactions of different variables on this process.

The objective of the current work is to determine the main and interactions effects of operating variables, using statistical techniques, on separation efficiency in Davis tube and find out optimum condition. This is done through a $2^{3}$ factorial design with mid-point replicates.

The different aims of optimization strategy used in this study are to design experimental tests (using factorial design) of separation in Davis tube. This is done to perform an analysis of the experimental results by ANOVA, to determine the significant factors influencing the separation process, and to find out the optimum conditions with this process.

\section{EXPERIMENTAL}

\subsection{Materials}

The experiments were run on a batch basis using a synthetic binary mixture. The mixture consists of magnetite and quartz with a percent of (1:1) by weight. Two size fractions of $(-400+315) \mu \mathrm{m}$ and $(-125+63) \mu \mathrm{m}$ of the two minerals were prepared for the tests. 


\subsection{Procedures}

The wet magnetic separation tests are conducted using a laboratory Davis tube tester [15]. Variables available for testing with this unit include magnetic field intensity between the poles, angle of inclination of the tube, rate of oscillation of the tube, particle size, and flow rate of wash water through the tube.

For the current work, the angle of inclination is fixed at $20^{\circ}$ from horizontal and the oscillation rate is maintained at $65 \mathrm{cycles} / \mathrm{min}$. Therefore, the chief variables investigated are the magnetic field intensity, which is varied by changing the current through the electromagnets, rate of wash water, and particle size.

Typically, $20 \mathrm{~g}$ of the mixture is mixed with $100 \mathrm{ml}$ of tap water and the mixture dispersed by either stirring in a beaker or rolling in a glass jar with small ceramic beads for a period of $5 \mathrm{~min}$ prior to the magnetic separation step. The tube is filled with tap water to above the level of the magnetic poles.

The magnet pole current is set to the desired level. Two different current levels, corresponding to two different magnetic field intensities, are tested. The field intensities selected are 1900 Gauss and 4300 Gauss, corresponding respectively to low and high settings for this apparatus.

The selected rate of wash water is between 300 and $500 \mathrm{ml} / \mathrm{min}$. The separation time is set at $5 \mathrm{~min}$. The magnetic field intensity between the poles, particle size, and wash water flow rate through the tube are set accordingly to the required values for each particular experiment.

The pulp sample is then added to the top of the Davis tube after which the oscillation motor and wash water are turned on. Sample collection then commences from the tube outlet.

The concentrate is removed from the tube at the end of each test by turning off the current to the magnets. The magnetic and non-magnetic products are collected, filtered, and dried to obtain the dry samples weights. All solid products are assayed to determine the contents of magnetite and quartz.

The recovery of magnetite, recovery of quartz, and separation efficiency of the concentrate are calculated using the following formulas:

$\% \mathrm{R}_{\mathrm{c}}($ magnetite $)=100 * \frac{\text { Total weight of concentrate } * \% \text { of magnetitein concentrate }}{\text { Total weight of feed } * \% \text { of magnetitein feed }}$

$\% \mathrm{R}_{\mathrm{c}}($ quartz $)=100 * \frac{\text { Total weight of concentrate } * \% \text { of quartz in concentrate }}{\text { Total weight of feed } * \% \text { of quartz in feed }}$

Separation efficiency $=\% \mathrm{R}_{\mathrm{c}}($ magnetite $)-\% \mathrm{R}_{\mathrm{c}}($ quartz $)$

\subsection{Variables}

The variables considered in this study are: the particle size $\left(\mathrm{X}_{1}\right)$, magnetic field intensity between the poles $\left(\mathrm{X}_{2}\right)$, and wash water flow rate through the tube $\left(\mathrm{X}_{3}\right)$. The variables studied and their levels are given in Table 1. All experiments were carried out under the same conditions except the variation of the desired variable. 
Table 1: The variables and levels of $2^{3}$ factorial design for magnetic separation process using Davis tube

\begin{tabular}{lccccc}
\hline \multicolumn{1}{c}{ Variables } & Code & $\begin{array}{c}\text { Low level } \\
(-1)\end{array}$ & $\begin{array}{c}\text { Base level } \\
(0)\end{array}$ & $\begin{array}{c}\text { High level } \\
(+1)\end{array}$ & $\begin{array}{c}\text { Step } \\
\text { size }\end{array}$ \\
\hline $\begin{array}{l}\text { Particle size, } \mu \mathrm{m} \\
\begin{array}{l}\text { Magnetic field intensity, } \\
\text { Gauss }\end{array}\end{array}$ & $\mathrm{X}_{1}$ & 094 & 226 & 358 & 132 \\
$\begin{array}{l}\text { Wash water rate, } \mathrm{cm}^{3} / \mathrm{min} \\
\text { ( }\end{array}$ & $\mathrm{X}_{3}$ & 300 & 400 & 500 & 100 \\
\hline
\end{tabular}

\subsection{Coding and General Form of Separation Efficiency Equation with Main and Interaction Effects}

Magnetic separation experiments were carried out according to the full factorial design of experiments [16]. The statistical design of experiments is used when the effect of several factors are studied in order to determine the main and interaction effects. When the effect of a factor depends on the level of another factor, the two factors are said to interact.

In this work, the variables studied were the particle size, magnetic field intensity, and wash water rate. Eight sets of trials are required according to the equation:

$$
\mathrm{N}=2^{\mathrm{n}}
$$

The variables and levels of $2^{3}$ full factorial design are presented in Table 1 . The higher level was designated as ' +1 ', lower level as ' -1 ', and base level as ' 0 '. The separation efficiency of the concentrate has been treated as "response". The matrix for three variables varied at two levels $(+,-)$ and the corresponding recovery of magnetite, recovery of quartz, and separation efficiency in the concentrate are shown in Table 2. According to the basic principle of the design of experiments, three experiments were carried out at the base level (Table 1) to estimate error and standard deviation [17].

The regression equation with interactive terms can be written as:

$$
Y=a_{0}+a_{1} X_{1}+a_{2} X_{2}+a_{3} X_{1} \cdot X_{2}+a_{4} X_{3}+a_{5} X_{1} \cdot X_{3}+a_{6} X_{2} \cdot X_{3}+a_{7} X_{1} \cdot X_{2} \cdot X_{3}
$$

Where: $a_{0}, a_{1}, a_{2}, a_{3}, a_{4}, a_{5}, a_{6}, a_{7}$ represent the coefficients.

Minitab statistical software is used for the analysis of experimental data from the randomized tests with designed conditions according to the format of the statistical program, which yielded the main and interaction effects that are specific to the magnetic separation process under investigation. The main effect of a factor is given as the change in a response produced by the change between the upper and lower level of that factor [17]. 
Table 2: $2^{3}$ full factorial design matrix for magnetic separation process using Davis tube

\begin{tabular}{ccccccc}
\hline \multirow{3}{*}{ Observation } & \multicolumn{3}{c}{ Coded factors } & \multicolumn{4}{c}{ Response } \\
\cline { 2 - 7 } & $\mathrm{X}_{1}$ & $\mathrm{X}_{2}$ & $\mathrm{X}_{3}$ & $\begin{array}{c}\mathrm{R}_{\mathrm{c}} \text { (magnetite), } \\
\%\end{array}$ & $\begin{array}{c}\mathrm{R}_{\mathrm{c}}(\text { quartz) } \\
\%\end{array}$ & $\begin{array}{c}\text { S.E., } \\
\%\end{array}$ \\
\hline & & & & & & \\
1 & - & - & - & 95.03 & 6.81 & 88.22 \\
2 & + & - & - & 64.57 & 11.89 & 52.68 \\
3 & - & + & - & 94.78 & 7.71 & 87.07 \\
4 & + & + & - & 74.20 & 1.09 & 73.11 \\
5 & - & - & + & 91.99 & 9.10 & 82.89 \\
6 & + & - & + & 69.92 & 2.71 & 67.21 \\
7 & - & + & + & 97.11 & 10.43 & 86.68 \\
8 & + & + & + & 76.66 & 2.59 & 74.07 \\
\hline
\end{tabular}

\section{RESULTS AND DISCUSSION}

The experimental data were analyzed statistically. The effect of the variables were quantified and interpreted.

\subsection{Statistical Analysis}

In the present work, three variables were taken into consideration to evaluate their main and interaction effects on the separation efficiency into the Davis tube in order to study the separation of magnetite from quartz. In other words, the main goal has been to establish the best set of variables that could be used in Davis tube to obtain maximum recovery of magnetite with an acceptable grade.

To study the main and interaction effects of the variables on the separation efficiency, a Yates' analysis and analysis of variance have been carried out [18]. The total variance (total mean square) of a factorial experiment can be divided into several sources using Yates' analysis. In case of un-replicated experiments, all the variance is subdivided between the effects.

$2^{3}$ experiments have $\left(2^{3}-1\right)$ degree of freedom, and Yates' analysis divides the total variation in the results into the 7 effects. It follows that each effect has one degree of freedom; hence, for any effect, the mean square equals the sum of squares. In Yates' analysis, the standard addition and subtraction in pairs is carried out by $n$ times for $\mathrm{n}$ factors. The Yates' analysis and analysis of variance for separation efficiency are given in Table 3.

Table 3: Results of statistical analysis and test of significance of main and interaction coefficients

\begin{tabular}{cccccccc}
\hline \multirow{2}{*}{ Code } & S.E. Exp, & \multicolumn{9}{c}{ Yates' analysis } & \multirow{2}{*}{ Effects } & $\mathrm{t}_{\text {cal. }}$ & \multirow{2}{*}{ Significance } \\
\cline { 4 - 6 } & $\%$ & 1 & 2 & 3 & & & \\
\hline & & & & & & & \\
Average & 88.22 & 140.90 & 301.07 & 611.93 & 76.491 & 257.75 & - \\
$\mathrm{X}_{1}$ & 52.68 & 160.17 & 310.86 & -77.77 & -9.721 & -32.76 & 99.95 \\
$\mathrm{X}_{2}$ & 87.07 & 150.10 & -49.49 & 29.92 & 3.740 & 12.60 & 99.5 \\
\hline
\end{tabular}




\begin{tabular}{cccccccc}
\hline $\mathrm{X}_{1} \mathrm{X}_{2}$ & 73.11 & 160.76 & -28.28 & 24.64 & 3.080 & 10.38 & 99.5 \\
$\mathrm{X}_{3}$ & 82.89 & -35.53 & 19.27 & 9.78 & 1.223 & 4.12 & $\mathrm{NS}$ \\
$\mathrm{X}_{1} \mathrm{X}_{3}$ & 67.21 & -13.97 & 10.65 & 21.22 & 2.652 & 8.94 & 99.5 \\
$\mathrm{X}_{2} \mathrm{X}_{3}$ & 86.68 & -15.68 & 21.56 & -8.61 & -1.077 & -3.63 & $\mathrm{NS}$ \\
$\mathrm{X}_{1} \mathrm{X}_{2} \mathrm{X}_{3}$ & 74.07 & -12.60 & 3.08 & -18.49 & -2.311 & -7.79 & 99 \\
\hline
\end{tabular}

NS $=$ not-significant at $99 \%$

The test of statistical significance of each effect necessitates estimation of experimental error. A confidence interval of $99 \%$ was chosen for determination of significance of main and interaction effects. In the current analysis with $\mathrm{n}=3$ factors, 3 center points have been used to estimate the experimental error and the variance, $\sigma^{2}$. The variance of main and interaction effects is given by [16]:

$$
\text { Variance }(\text { Effects })=\frac{\sigma^{2}}{2^{n}}
$$

$\mathrm{t}_{\text {cal. }}=[$ Calculated main or interaction effect $/ \sqrt{(\text { Variance (Effects)) }}] \geq \mathrm{t}_{0.01,2}$

The value of $t_{0.01,2}$ is 6.96 , which can be obtained from the Student's $t-$ distribution table and if the estimated main and interaction effects are significant at 99\% confidence level, then they will satisfy the above criteria [19]. In other words, an effect is considered to be significance if its significance level is greater than $99 \%$. The details are given in Table 3.

On eliminating the coefficients which are not significant, the statistical model can be built up for prediction of separation efficiency using Yates' analysis data (Tables 3). This model can be used to perform analysis of the residues to check the assumption on the experimental error distribution of the factorial design [20]. The regression equation formed for separation efficiency, using the effects of variables significant at 99\% confidence level or more, (Eq. (5)) becomes:

$$
\text { S.E. }=76.491-9.721 X_{1}+3.740 X_{2}+3.080 X_{1} \cdot X_{2}+2.652 X_{1} \cdot X_{3}-2.311 X_{1} \cdot X_{2} \cdot X_{3}
$$

$$
\mathrm{R}^{2}=0.98005 \text { and Adjusted } \mathrm{R}^{2}=0.93016
$$

where S.E. is the separation efficiency of the concentrate. $X_{1}, X_{2}, X_{3}$ are expressed in coded form -1 or +1 . The coefficient of determination $\left(\mathrm{R}^{2}\right)$ and adjusted $\mathrm{R}^{2}$ are used to check the model ability to predict the response (separation efficiency) accurately. These were determined from the following equations [21]:

$$
\mathrm{R}^{2}=1-\left[\sum\left\{\left(\mathrm{S} . \mathrm{E}_{\text {exp }}-\mathrm{S} . \mathrm{E}_{\mathrm{prd}}\right)^{2}\right\} / \sum\left\{\left(\mathrm{S} . \mathrm{E}_{\exp }-{\left.\left.\mathrm{S} . \mathrm{E}_{\text {exp }}\right)^{2}\right\}}^{-}\right]\right.\right.
$$

where S.E.prd is the predicted response variable and S.E. ${ }_{\text {exp }}$ is the mean experimental value of separation efficiency. If $R^{2}$ is 1 , then the prediction is nearly perfect. 
However, if $\mathrm{R}^{2}$ becomes zero, the model has little value. The empirical model was found to accurately estimate the response variable as indicated by $R^{2}$ value $(0.98)$. The residual analysis for separation efficiency was given in Fig. 1.

$$
\text { Adjusted } \mathrm{R}^{2}=\mathrm{R}^{2}-[(k-1) /(N-k)] *\left(1-R^{2}\right)
$$

where $\mathrm{k}$ is the number of independent variables (number of significant coefficients in the regression equation) and $\mathrm{N}$ is the number of trials.

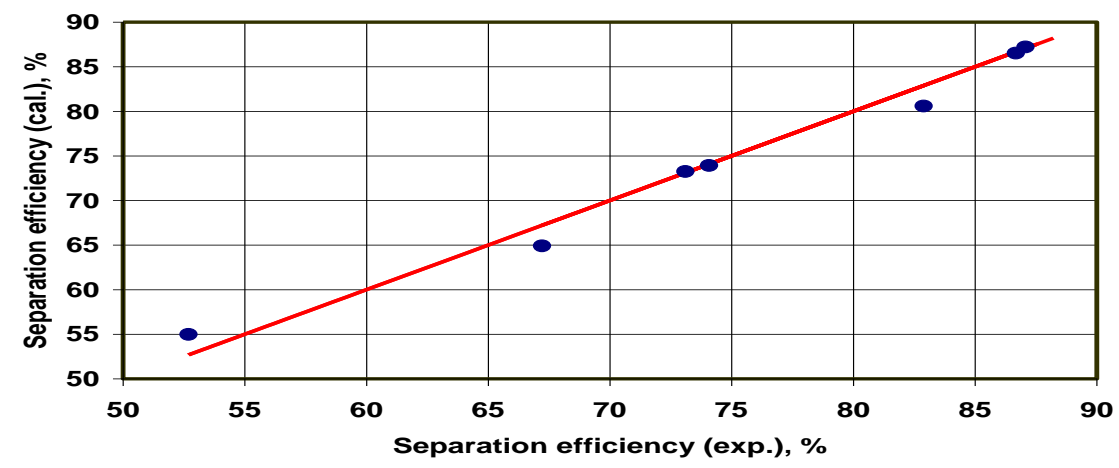

Fig. 1: Residuals analysis of separation efficiency in Davis tube

The effect of variables on separation efficiency in Davis tube is shown in Fig. 2. The main effects of all the variables are significant at $99 \%$ confidence level except of the wash water rate. The order of influence is $X_{1}>X_{2}>X_{3}$. The most important effect is the particle size $\left(\mathrm{X}_{1}\right)$. It is highly significant but negative. Of course this variable will influence contrary the separation efficiency. The effect of magnetic field intensity $\left(\mathrm{X}_{2}\right)$ is also significant and positive. Although the variable wash water rate $\left(\mathrm{X}_{3}\right)$ has positive effect, it is not significant at $99 \%$ confidence level. The interpretation of variables effects on separation efficiency are explained in detail in the following sections.

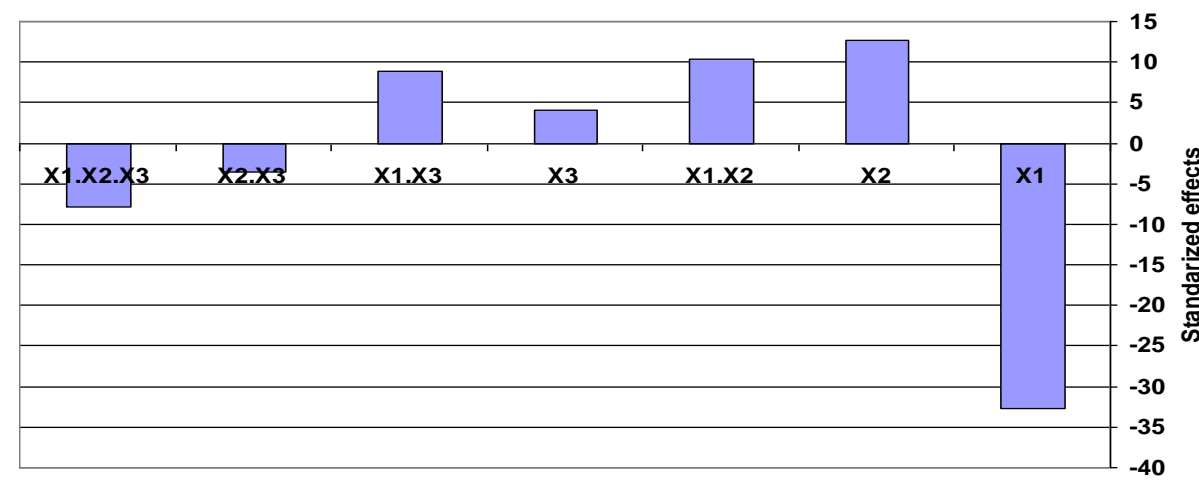

Factors

Fig. 2: Pareto chart of the standardized effects of separation efficiency in Davis tube, $\alpha=0.01$ 
The forces acting upon particles in a magnetic separator are magnetic, gravity, drag, friction, inertia and centrifugal. Relative importance of each force varies with separator design. However, magnetic, gravity and hydrodynamic drag forces are the major forces that govern the overall behavior of mineral particles in a magnetic separator [2,22]. Obviously, while the magnetic forces attract magnetic particles, gravity and drag forces work against magnetic forces.

Particle size of minerals has a pronounced effect on the magnitude of these forces. It has been reported that while the hydrodynamic drag forces are proportional to the diameter of particles, the magnetic and gravity forces are proportional to the second and third power of the particle diameter, respectively. Thus, while the hydrodynamic drag forces become more dominant for the fine particles, the gravity forces are dominant for the coarse particles and magnetic forces for the intermediate size range. Because the force of attraction is directly proportional to the particle mass, the larger particles require higher magnetic intensity than for fines [23].

In magnetic separation of fine particles, magnetic forces must overcome the hydrodynamic drag forces but magnetic forces must be greater than the gravity forces for the coarse mineral particles [2]. Hence, as the particle size increases, the gravity force will be further increased and it may be also greater than the magnetic force. This leads to decrease the recovery of coarse magnetic particles and accordingly to decrease the separation efficiency.

It can be decided that the non-significant effect of wash water rate on the separation efficiency may be attributed to that the magnitude of the magnetic force exceeds the fluid drag force exerted on such particles. This means that the gravity and magnetic forces are more dominant than the drag force.

As the magnetic field intensity increases, magnetic particles are usually picked up effectively by magnetic separators, resulting in an increase of valuable minerals, and hence the increase of separation efficiency [2].

From Eq. (8), it can also be revealed that, although the particle size $\left(\mathrm{X}_{1}\right)$ has negative significant effect on the separation efficiency, its interaction with magnetic field intensity $\left(X_{1} \cdot X_{2}\right)$ is also significant at $99 \%$ level but has positive effect. This interaction $\left(\mathrm{X}_{1} \cdot \mathrm{X}_{2}\right)$ has the highest significant effect on the separation efficiency. Moreover, the non-significant variable wash water rate $\left(\mathrm{X}_{3}\right)$, which has positive effect, interacts with the negative effect variable particle size $\left(X_{1} \cdot X_{3}\right)$ and increases also the separation efficiency positively. The three studied variables interact together $\left(\mathrm{X}_{1} \cdot \mathrm{X}_{2} \cdot \mathrm{X}_{3}\right)$. This interaction is significant at $99 \%$ confidence level but has negative affect, i.e. it decreases the separation efficiency.

The non-magnetic forces that are used deliberately to assist in separation may interact either with or against the magnetic force. The magnitude and direction of the resultant force can be varied by changing either these forces or the magnetic force [23].

\subsection{Optimization}

One of the techniques of optimization is the method of steepest ascent, in which the base point is assumed and the next set of values is selected, which is proportional to product of the coefficient and step size. The selected values are incremented successively and objective function is evaluated each time till the optimum point is reached. 
In this work, our objective was to maximize the separation efficiency in the concentrate product of Davis tube. Eq. (8) was used to determine the increment size for separation efficiency. The variables having positive effects were increased and the variables having negative effects were decreased according to the increment size (Table 4) and evaluated by carrying out successive experiments. The results obtained with their variables are given in Table 5.

Table 4: Results of evaluation of optimized variables for optimum separation efficiency in Davis tube

\begin{tabular}{lccc}
\hline \multicolumn{1}{c}{ Variable } & $\begin{array}{c}\text { Particle size, } \\
\mu \mathrm{m}\end{array}$ & $\begin{array}{c}\text { Magnetic field } \\
\text { intensity, Gauss }\end{array}$ & $\begin{array}{c}\text { Wash water rate, } \\
\mathrm{cm}^{3} / \mathrm{min}\end{array}$ \\
\hline Principal level, $\mathrm{Z}_{\mathrm{j} 0}$ & 225.750 & 3100 & \\
Increment, $\Delta \mathrm{Z}_{\mathrm{j}}$ & 131.750 & 1200 & 400 \\
Coefficient, $\mathrm{b}_{\mathrm{j}}$ & -9.721 & 3.740 & 100 \\
$\Delta \mathrm{Z}_{\mathrm{j}}^{*} \mathrm{~b}_{\mathrm{j}}$ & -1280.749 & 4488.531 & 1.223 \\
Normal steps & -0025.615 & 0089.771 & 122.257 \\
\hline
\end{tabular}

Table 5: Optimization of separation efficiency in Davis tube

\begin{tabular}{cccccc}
\hline \multicolumn{2}{c}{ Variables } \\
$\begin{array}{c}\text { particle size } \\
\left(\mathrm{X}_{1}\right), \mu \mathrm{m}\end{array}$ & $\begin{array}{c}\text { Magnetic field } \\
\text { intensity }\left(\mathrm{X}_{2}\right), \\
\text { Gauss }\end{array}$ & $\begin{array}{c}\text { Wash water } \\
\text { rate }\left(\mathrm{X}_{3}\right), \\
\mathrm{cm}^{3} / \mathrm{min}\end{array}$ & $\begin{array}{c}\mathrm{R}_{\mathrm{c}} \text { (magnetite), } \\
\%\end{array}$ & $\begin{array}{c}\mathrm{R}_{\mathrm{c}} \text { (quartz), } \\
\%\end{array}$ & $\begin{array}{c}\text { S.E., } \\
\%\end{array}$ \\
\hline 200.135 & 3189.771 & 402.445 & 87.18 & 0.85 & 86.33 \\
174.520 & 3279.541 & 404.890 & 83.77 & 7.02 & 76.75 \\
148.905 & 3369.312 & 407.335 & 79.71 & 3.74 & 75.97 \\
\hline
\end{tabular}

Table 3 indicates that the effects of magnetic field intensity $\left(\mathrm{X}_{2}\right)$ and wash water rate $\left(\mathrm{X}_{3}\right)$ are positive, whereas that of particle size $\left(\mathrm{X}_{1}\right)$ is negative. The results of the experiments are given in Table 5. The optimum condition was found to be at particle size about $200 \mu \mathrm{m}$, magnetic field intensity 3190 Gauss, and wash water rate $402 \mathrm{~cm}^{3} / \mathrm{min}$. At these conditions, a concentrate with $98.9 \%$ magnetite at $87.2 \%$ component recovery and $86.3 \%$ separation efficiency was obtained.

\section{CONCLUSIONS}

The main effects of all the variables on the separation efficiency were significant at 99\% confidence level except of the wash water rate. The order of influence was: particle size $>$ magnetic field intensity $>$ wash water rate. The most important effect was the particle size which had a negative response. The effect of magnetic field intensity was also significant, but positive. The wash water rate had positive effect but not significant. The empirical model was found to accurately predict the separation efficiency where the coefficient of determination was about 0.98. An optimum concentrate with $98.9 \%$ magnetite at $87.2 \%$ component recovery and $86.3 \%$ separation 
efficiency was obtained at particle size about $200 \mu \mathrm{m}$, magnetic field intensity 3190 Gauss, and wash water rate $402 \mathrm{~cm}^{3} / \mathrm{min}$.

\section{REFERENCES}

[1] G. Özbayoglu, Ç. Hosten, Ü. Atalay, C. Hiçyilmaz and A.I. Arol (Eds.): 'Mineral processing on the verge of the 21st century', In: Proceedings of the Eighth International Mineral Processing Symposium, Antalya, Turkey, 16-18 October 2000, Balkema, Rotterdam, p. 271, 2000.

[2] A.I. Arol and A. Aydogan: 'Recovery enhancement of magnetite fines in magnetic separation', Colloids and Surfaces A: Physicochem. Eng. Aspects, 232, 151-154, 2004.

[3] W.J. Bruckard, K.J. Davey, T. Rodopoulos, J.T. Woodcock and J. Italiano: 'Water leaching and magnetic separation for decreasing the chloride level and upgrading the zinc content of EAF steelmaking baghouse dusts', Int. J. Miner. Process., 75, 1-20, 2005.

[4] M. Ito, K. Kashiwaya, N. Sumiya, N. Hiroyoshi and M. Tsunekawa: 'Anode activating agent recovery by magnetic separation from the $<0.075 \mathrm{~mm}$ fraction of crushed nickel metal hydride batteries from hybrid vehicles', Separation and Purification Technology, 69, 149-152, 2009.

[5] J.G. Rayner and T.J. Napier-Munn: 'The mechanism of magnetics capture in the wet drum magnetic separator', Minerals Engineering, 13 (3), 277-285, 2000.

[6] R. Sripriya, A. Dutta, P.K. Dhall, M. Narasimha, V. Kumar and B.S. Tiwari: 'An analysis of medium losses in coal washing plants', Int. J. Miner. Process., 80, 177-188, 2006.

[7] D.P. Obeng and S. Morrell: 'The JK three-product cyclone-performance and potential applications', Int. J. Miner. Process., 69, 129-142, 2003.

[8] D. Tao, S. Chen, B.K. Parekh and M.T. Hepworth: 'An investigation of a thermochemical process for conversion of gypsum and pyrite wastes into useful products', Advances in Environmental Research, 5, 277-284, 2001.

[9] P.K. Naik: 'Quantification of induced roll magnetic separation of mineral sands', Scandinavian Journal of Metallurgy, 31 (6), 367-373, 2002.

[10] P.K. Naik, L.B. Sukla and S.C. Das: 'Aqueous $\mathrm{SO}_{2}$ leaching studies on Nishikhal manganese ore through factorial experiment', Hydrometallurgy, 54, 217-228, 2000.

[11] R.N. Sahoo, P.K. Naik and S.C. Das: 'Extraction of manganese from low grade manganese ore using oxalic acid as reductant', Hydrometallurgy, 62 (3), 157163, 2001.

[12] P.K. Naik, L.B. Sukla and S.C. Das: 'Application of statistical design in the leaching study of low grade manganese ore using aqueous sulfur dioxide', Separation Science and Technology, 37 (6), 1375-1389, 2002.

[13] P.K. Naik, L.B. Sukla and S.C. Das: 'Extraction of manganese from low grade Nishikhal ore using pyritiferous lignite in acidic medium', Minerals and Metallurgical Processing, 19 (2), 110-112, 2002.

[14] P.K. Naik, P.S.R. Reddy and V.N. Misra: 'Optimization of coal flotation using statistical technique’, Fuel Process. Technol., 85, 1473-1485, 2004. 
[15] D.M. Hopstock: 'Measurement of electrical and magnetic properties of minerals', In: N.L. Weiss (Ed.), SME Mineral Processing Handbook, Society of Mining Engineers of American Institute of Mining, Metallurgical, and Petroleum Engineers, New York, Section 30, 70- 80, 1985.

[16] S. Akhanazarova and V. Kafarov, 'Experiment Optimization in Chemistry and Chemical Engineering', Mir Publishers, Moscow, 1982.

[17] D.C. Montgomery and G.C. Runger: 'Applied Statistics and Probability for Engineers', $3^{\text {rd }}$ edn, 2002.

[18] L. Davies: 'Efficiency in research, development, and production', The Statistical Design and Analysis of Chemical Experiments, The Royal Society of Chemistry, Cambridge, UK p. 180, 1993.

[19] S. Kelebek, U. Demir, O. Sahbaz, A. Ucar, M. Cinar, C. Karaguzel and B. Oteyaka: 'The effects of dodecylamine, kerosene and $\mathrm{pH}$ on batch flotation of Turkey's Tuncbilek coal', Int. J. Miner. Process., 88, 65-71, 2008.

[20] D.C. Montgomery: 'Design and Analysis of Experiments', Wiley, Singapore, $3^{\text {rd }}$ edn, 1991.

[21] P. K. Naik, P. S. R. Reddy, V. N. Misra: 'Interpretation of interaction effects and optimization of reagent dosages for fine coal flotation', Int. J. Miner. Process., 75, 83-90, 2005.

[22] B.A. Wills: 'Magnetic and Electrical Separation', (ed. T. Napier-Munn), Mineral Processing Technology, Elsevier, Amsterdam, $7^{\text {th }}$ edn, Ch. 13, 353-372, 2006.

[23] H.G. Vijayendra: 'Magnetic Separation', A Handbook on Mineral Dressing, Vikas Publishing House PVT LTD, New Delhi, $2^{\text {nd }}$ edn, 271-279, 2001.

\section{تطبيق طريقة العوامل لتركيز الخامات بإستخدام أنبوية ديفيذ للفصل المغناطيسى}

في هذا البحث تم عمل دراسة طبقا لطريقة العوامل للنحليل الإحصائي بإستخدام أنبوبة ديفيذ للفصل المغناطيسى.

المتغيرات التي تم دراستها هي حجم الحبيبات - كثافة المجال المغناطيسى - معدل ماء الغسيل. ثم تم عمل التجارب على خليط ثنائي من الكوارتز والمجناتيت بنسب وزنيـه منساوية حيث تم تحديد القيم

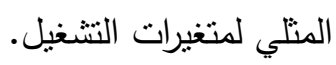

تم الحصول على منتج بنسبة 98.9\% ماجناتيت و باسترجاع قدره 87.2\% بكفاءة فصل 86.3\% في في الركاز . هذا المنتج نم الحصول عليه عند الظروف القصوى للنتشغيل وهى كالآتي: حجم الحبيبات 200 مبكرون، كثافة المجال المغناطيسى 3190 جاوس, و أخيرا 402 سم²/دقيقة معدل ماء الغسيل.

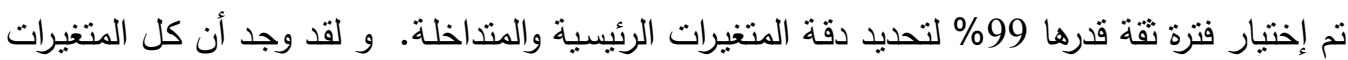

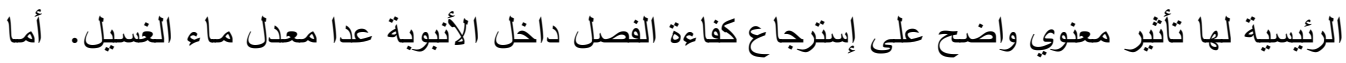

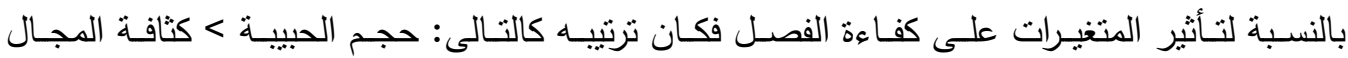
المغناطيسى > معدل ماء الغسيل. مع ملاحظة أن حجم الحبيبة كان هو الأكثر تأثثرا ولكن كان تأثثره 
سلبيا و كثافة المجال المغناطيسى كان أيضا ذو تأثير كبير ولكن بصوره إيجابية. معدل ماء الغسيل كان أيضا إيجابيا و لكن تأثثره كان محدود للغاية. و فى النهاية حصلنا على نموذج رياضي دقيق لتحديد كفاءة الفصل داخل الأنبوبة حيث كان معامل الإزتباط للنتائج مقداره 